\title{
Healthcare waste management: what do the health workers in a Nigerian tertiary hospital know and practice
}

\author{
Emmanuel Chukwunonye Azuike ${ }^{1, ~ *, ~ E c h e n d u ~ D o l l y ~ A d i n m a ~}{ }^{1}$, Simeon Achunam Nwabueze ${ }^{1}$, \\ Ebele Dabeluchukwu Azuike ${ }^{2}$, Victor Ahoma Mbanuzuru', Uzoamaka Ugochinyere Epundu', \\ Kenechukwu Grace Enwonwu ${ }^{1}$, Nkiru Ifeoma Chikezie ${ }^{1}$, Chioma Chetachukwu Ajator ${ }^{1}$, \\ Emeka Michael Onebunne ${ }^{1}$, Darlington Chukwudinma Obi ${ }^{1}$ \\ ${ }^{1}$ Department of Community Medicine, Nnamdi Azikiwe University Teaching Hospital, Nnewi, Anambra State, Nigeria \\ ${ }^{2}$ Department of Nursing Sciences, Faculty of Health Sciences, College of Health Sciences, Nnamdi Azikiwe University, Awka, Anambra \\ State, Nigeria
}

\section{Email address:}

emmanazuike@yahoo.com (E. C. Azuike)

\section{To cite this article:}

Emmanuel Chukwunonye Azuike, Echendu Dolly Adinma, Simeon Achunam Nwabueze, Ebele Dabeluchukwu Azuike, Victor Ahoma Mbanuzuru, Uzoamaka Ugochinyere Epundu, Kenechukwu Grace Enwonwu, Nkiru Ifeoma Chikezie, Chioma Chetachukwu Ajator, Emeka Michael Onebunne, Darlington Chukwudinma Obi. Healthcare Waste Management: What do the Health Workers in a Nigerian Tertiary Hospital Know and Practice. Science Journal of Public Health. Vol. 3, No. 1, 2015, pp. 114-118. doi: 10.11648/j.sjph.20150301.30

\begin{abstract}
Introduction: Healthcare waste is any solid or liquid waste that is generated in the diagnosis, treatment or immunization of human beings or animals, in research pertaining thereto, or in production or testing of biologicals. Mismanagement of healthcare waste poses risks to people and the environment. Improving the standards of healthcare waste management protects the health and safety of healthcare workers, patients, visitors to healthcare facilities and the general public. This study was carried out to determine the knowledge and practice of healthcare waste management by the healthcare workers in Nnamdi Azikiwe University Teaching Hospital Nnewi, Nigeria. Methods: This was a cross-sectional descriptive study. There hundred and thirty one healthcare workers who have been in the employment of Nnamdi Azikiwe University Teaching Hospital were recruited into the study by proportionate sampling technique. Data was collected using a semistructured self-administered questionnaire. Data was analyzed using SPSS version 17. A p-value $<0.05$ was considered significant. Results: One hundred and seventy nine (54.1\%) of the respondents were males while 149 (45\%) were females. The commonest age group was $25-34$ years $(49.5 \%)$. Three hundred and twenty $(96.7 \%)$ of the respondents had tertiary education, $8(2.4 \%)$ had secondary education, while $3(0.9 \%)$ had primary education and none of the respondents had no education at all. One hundred and twenty six (38.1\%) of the respondents have worked for the hospital for 2-4 years while 4 (1.2\%) have worked for greater than or equal to 20 years. The knowledge of healthcare waste management among the healthcare workers was high. But the practice was not optimal. Conclusion: The healthcare workers had a high level of knowledge regarding healthcare waste management but practice amongst the workers was not adequate.
\end{abstract}

Keywords: Knowledge, Practice, Healthcare Waste, Healthcare Workers

\section{Introduction}

Healthcare waste is all the waste generated by healthcare establishments, research facilities and laboratories. ${ }^{1}$ It is also defined as waste from natal care, diagnosis, treatment or prevention of disease in humans or animals and also wastes produced in non-healthcare environments such as university research laboratories. ${ }^{2}$ It also refers to any solid or liquid waste that is generated in the diagnosis, treatment or immunization of human beings or animals, in research pertaining thereto, or in production or testing of biologicals. ${ }^{3}$ Between $75 \%$ and $90 \%$ of waste produced by healthcare providers is non-risk or "general" healthcare waste. ${ }^{1}$ The remaining 10 to $25 \%$ of healthcare waste is regarded as hazardous and may create a variety of health risks. ${ }^{1}$

Mismanagement of healthcare waste poses risks to people and the environment. Transmission of disease generally occurs through injuries from contaminated sharps. Infections of particular concern are hepatitis B (HBV), Hepatitis C (HCV) and the human immunodeficiency virus (HIV). HBV 
for example can remain infectious for a week, even when dried at room temperature, and the probability that a single needle stick injury will result in seroconversion is approximately 30\%. ${ }^{4}$ World Health Organization (WHO) estimates that each year there are about 8 to 16 million new cases of hepatitis B Virus (HBV), 2.3 to 4.7 million cases of Hepatitis C Virus (HCV) and 80,000 to 160,000 cases of human immunodeficiency Virus (HIV) due to unsafe injections and mostly due to poor waste management systems. ${ }^{5}$ In the developed world, the level of knowledge of healthcare waste management among healthcare workers is generally high, however there are some results of some studies which report a low knowledge among the healthcare workers. A study done in Portugal reported a high level of knowledge among the health workers; $76 \%$ among the nurses and $64.8 \%$ among the doctors. ${ }^{6}$ This was corroborated by a study done in Canada which reported that the knowledge of healthcare waste management was high. ${ }^{7}$

In the developing countries the level of knowledge of healthcare waste management among the workers is generally low. This has been reported by several studies. A study done in South Africa reported that there was poor knowledge among the health workers on key documents regulating healthcare waste management. ${ }^{8}$ Similarly the findings of a study done in Agra India reported a low level of knowledge of healthcare waste management rules among the healthcare workers. ${ }^{9}$ This is similar to the report of a study done in Kolar district India which reported that the paramedical staff had low knowledge of appropriate waste management rules. ${ }^{10}$ Another study in a tertiary hospital in New Delhi, India reported a high knowledge of biomedical waste management rules among the doctors $(81 \%)$ but a low knowledge among the laboratory staff $(12 \%)$ and sanitary staff $(14 \%) .{ }^{11}$ In India a study reported that only about $1.6 \%$ of the paramedics studied, knew about the categories of biomedical waste correctly. ${ }^{12}$ In Gaza it was reported that only $55.8 \%$ of the medical workers studied, knew that viral hepatitis could be transmitted as a result of improper management of medical waste. ${ }^{13}$ A study done in Edo state Nigeria reported that only $46 \%$ of the healthcare workers (doctors and nurses) understood the importance of healthcare waste management in the provision of safety to the public. ${ }^{14}$ This study was carried out to determine the knowledge and practice of healthcare workers in Nnamdi Azikiwe University Teaching Hospital (NAUTH) Nnewi regarding healthcare waste management.

\section{Methodology}

This was a Cross-sectional Descriptive study carried out at Nnamdi Azikiwe University Teaching Hospital (NAUTH), a tertiary healthcare facility located in Nnewi, Nnewi-North Local Government Area (LGA) of Anambra State, Nigeria. NAUTH provides a wide range of specialized medical, surgical, diagnostic, out-patient, in-patient, rehabilitative and support services. The hospital has 250 beds. ${ }^{15}$ The study population was the healthcare workers in NAUTH, Nnewi. The workers include 412 doctors, 317 nurses, 15 pharmacists,
84 medical laboratory scientists, 20 orderlies and 8 dustmen, giving a total of 856 health workers. Only health workers who have been in the employment of the hospital for at least one year, who gave their consent and who fell into one of the following categories were included: Doctors, nurses, pharmacists, laboratory scientists, orderlies, dustmen.

\section{Sample Size Determination}

Formula for sample size determination for cross sectional descriptive studies ${ }^{16}$ :

For population $>10,000$ :

$$
n=\frac{z^{2} p q}{d^{2}}
$$

$\mathrm{n}=$ Desired sample size

$\mathrm{z}=$ Standard normal deviate, usually set at 1.96 .

$\mathrm{p}=$ Proportion in the target population estimated to have a particular characteristic. In this case, $46 \%$ (ie 0.46 ) was used, which is the proportion of healthcare workers who understood the importance of healthcare waste management in the provision of safety to the public according to a study titled "Healthcare waste management in Nigeria: A case study". 6

$$
\mathrm{q}=1.0-\mathrm{p}(\text { ie } 1-0.46)=0.54
$$

$\mathrm{d}=$ degree of accuracy, usually set at 0.05 .

Therefore:

$$
n=\frac{(1.96)^{2} * 0.46 * 0.54}{0.05^{2}}=384
$$

The population of the healthcare workers is 856 which is less than 10,000 . Hence the formula for populations $<10,000$ was applied. $^{35}$

$$
n f=\frac{n}{1+\frac{n}{N}}
$$

where:

$\mathrm{nf}=$ desired sample size when population is $<10,000$

$\mathrm{n}=$ sample size if population is $>10,000$

$\mathrm{N}=$ Population size

$\mathrm{n}=384$

$\mathrm{N}=856$

Therefore:

$$
n f=\frac{384}{1+\frac{384}{856}}
$$

$\mathrm{nf}($ sample size $)=265$.

An adjustment of the sample size estimate to take care of attrition was made by dividing the calculated sample size by the anticipated response rate. ${ }^{16}$ A study on knowledge of health workers regarding healthcare waste reported a response rate of 
$80 \% .{ }^{8}$ Using $80 \%$ as the anticipated response rate in this study the minimum sample size was calculated as follows:

$$
\frac{265}{0.80}=331
$$

Proportionate sampling technique was used to select 331 health workers that participated in the study. A semistructured, self-administered questionnaire was used, but for the lower cadre of workers it was interviewer administered. Data was analyzed using a licensed Statistical Package for Social Sciences (SPSS) software, version 20. Statistical significance was set at $p$ value $<0.05$. Ethical approval for this study was obtained from the NAUTH ethical committee, and a written informed consent was obtained from each of the respondents.

We also wish to point out the following limitations in this study: Convenience sampling was used after stratifying the workers into job categories instead of systematic sampling because the management could not release the list of workers in each job category. We were unable to measure the quantity of the different kinds of waste generated in the hospital. This was because the wastes were not segregated.

\section{Results}

The calculated sample size was 331, therefore 331 questionnaires were administered and all were retrieved and analyzed. The response rate was $100 \%$.

Table 1. Distribution of respondents by demographic characteristics, job categories, and duration of employment.

\begin{tabular}{|c|c|c|}
\hline Variable & Frequency & Percentage \\
\hline \multicolumn{3}{|l|}{ Sex } \\
\hline Male & 179 & 54.1 \\
\hline Female & 149 & 45 \\
\hline Missing & 3 & 0.9 \\
\hline \multicolumn{3}{|c|}{ Age (in years) } \\
\hline$<25$ & 5 & 1.5 \\
\hline $25-34$ & 164 & 49.5 \\
\hline $35-44$ & 121 & 36.6 \\
\hline $45-54$ & 27 & 8.2 \\
\hline$\geq 55$ & 9 & 2.7 \\
\hline \multicolumn{3}{|l|}{ Job category } \\
\hline Doctors & 159 & 48 \\
\hline Nurses & 123 & 37.2 \\
\hline MLS & 32 & 9.7 \\
\hline Orderlies & 8 & 2.4 \\
\hline Pharmacists & 6 & 1.8 \\
\hline Dustmen & 3 & 0.9 \\
\hline \multicolumn{3}{|c|}{ Educational level } \\
\hline Tertiary & 320 & 96.7 \\
\hline Secondary & 8 & 2.4 \\
\hline Primary & 3 & 0.9 \\
\hline \multicolumn{3}{|c|}{ Duration of employment(yrs) } \\
\hline$<2$ & 85 & 25.7 \\
\hline $2-4$ & 126 & 38.1 \\
\hline $5-9$ & 83 & 25.1 \\
\hline $10-14$ & 21 & 6.3 \\
\hline $15-19$ & 11 & 3.3 \\
\hline$\geq 20$ & 4 & 1.2 \\
\hline Missing & 1 & 0.3 \\
\hline
\end{tabular}

Table 1 shows the demographic characteristics of the respondents. As shown in the table, $54.1 \%$ of the respondents were males, $45 \%$ females, $3(0.9 \%)$ respondents did not indicate their sex. The highest occurring age group was 25-34 years $(49.5 \%)$, while the least occurring age group was $<25$ years $(1.5 \%)$. The mean age was 35.12 years +6.9 years. $48 \%$ of the respondents were doctors, $37.2 \%$ were nurses, while $0.9 \%$ were dustmen. The commonest educational level of the respondents was tertiary education $(96.7 \%)$ and least was primary education $(0.9 \%)$.

Table 2. Knowledge of respondents regarding healthcare waste management.

\begin{tabular}{llll}
\hline Question & Responses & Frequency & Percentage \\
\hline Is healthcare waste & Yes & 329 & 99 \\
hazardous? & No & 2 & 1 \\
No of hazards of HCW & 2 & 309 & 93 \\
identified & 1 & 22 & 7 \\
& 5 & 184 & 55.6 \\
No of categories of HCW & 3 & 55 & 16.6 \\
identified & 4 & 44 & 13.3 \\
& 2 & 48 & 14.5 \\
& 1 & 0 & 0.0 \\
& 0 & 0 & 0.0 \\
\hline
\end{tabular}

Table 2 depicts the results of questions that border on the knowledge of the healthcare workers. $99 \%$ of the respondents agreed that healthcare waste is hazardous. $93 \%$ of the respondents were able to identify the two hazards of healthcare waste in the questionnaire, $7 \%$ identified only one hazard and none of the healthcare workers could not identify any. $55.6 \%$ of the respondents were able to identify all the five categories of healthcare waste, $16.6 \%$ were able to identify 4 categories, $13.3 \%$ identified 3 categories, $14.5 \%$ identified 2 categories, none of the respondents identified only one category, and none identified none of the categories

Table 3. Practice of how management by the health workers.

\begin{tabular}{cccl}
\hline Variable & Response & Frequency & Percentage \\
\hline Do you recap needles sometimes? & & \\
Yes & 194 & 58.6 \\
No & 132 & 39.9 \\
Missing & 5 & 1.5 \\
How often do you discard sharps into safety boxes? & \\
Always & 238 & 71.9 \\
Sometimes & 89 & 26.9 \\
Never & 3 & 0.9 \\
How often do you use gloves? & & \\
Always & 229 & 69.2 \\
Sometimes & 99 & 29.9 \\
Never & 2 & 0.6 \\
Missing & 1 & 0.3 \\
\hline
\end{tabular}

Table 3 shows the results of questions that border on the practice of healthcare waste management by the respondents. In response to the question "do you recap needles at least sometimes?" 194 (58.6\%) of the respondents replied "yes", $39.9 \%$ replied "no", $5(1.5 \%)$ of the respondents did not respond. In response to the question "how often do you discard sharps into the safety box?" 238 (71.9\%) of the respondents replied "always", 26.9\% replied "sometimes", $0.9 \%$ replied "never", one respondent $(0.3 \%)$ did not reply. 
Asked about the frequency of use of gloves 229 (69.2\%) replied "always", 29.9\% replied 'sometimes", 0.6\% replied "never", one respondent $(0.3 \%)$ did not reply.

\section{Discussion}

This cross-sectional descriptive study aimed to determine the knowledge and practice of healthcare waste management by health workers in Nnamdi Azikiwe University Teaching Hospital, Nnewi. The knowledge of the respondents on hazards of healthcare waste was high as demonstrated by the fact that $93 \%$ of the workers were able to identify correctly the two hazards of healthcare waste in the questionnaire. Also $85 \%$ of the health workers were able to identify correctly at least three out of the five categories of healthcare waste. This agrees with the findings of a study done in India which reported that $91.7 \%$ of the health workers had knowledge. ${ }^{10} \mathrm{It}$ also agrees with the findings of another study in India which reported a high knowledge (86\%) among the health workers. ${ }^{11}$ On the contrary a study done in Egypt reported a poor knowledge of the healthcare workers regarding healthcare waste management. ${ }^{18}$

In this study, a probe into the practice of recapping needles among the healthcare workers revealed that $58.6 \%$ of the workers recap needles at least sometimes. Also the practice of discarding of sharps into the safety boxes is high. $72 \%$ of the health workers replied that they discard sharps into the safety box "always", 27\% replied "sometimes", while only $1 \%$ replied "never". This agrees with the findings of a study done in India. ${ }^{11}$ This finding is also similar to the findings of a study done in South Africa which reported that $90 \%$ of the healthcare workers discarded sharps into the safety box always. ${ }^{8}$ A lower level was reported in Gaza. ${ }^{13}$ A contrasting finding was reported in Egypt where the practice of disposal of sharps by the healthcare workers was considered low by the researchers. ${ }^{18}$ Another aspect of the practice of healthcare waste management by the workers is the practice of wearing gloves. Among the healthcare workers in this study $69.2 \%$ use gloves "always". This figure contrasts with $31.48 \%$ reported in Agra, India. ${ }^{19}$

\section{Conclusion and Recommendation}

The level of knowledge of the healthcare workers of healthcare waste management was high, The practice of discarding sharps into the safety box by the healthcare workers was high. The practice of recapping needles sometimes was high. Use of gloves by the healthcare workers was at an unacceptable level.

Recommendation is therefore made for the management of the hospital organize training of all the new healthcare workers on HCW management. And there should be periodic refresher courses for existing staff. The government of the country should formulate appropriate institutional and national policies on $\mathrm{HCW}$ and also enforce the policies nationwide.

\section{References}

[1] WHO. Healthcare waste management. Available online at http://www.who.int/wastesanitaionhealth/medicalwaste/002to 019pdf. Accessed on 1 July 2014.

[2] Imperial College London. Healthcare waste generic definitions. Available online at http://www3.imperial.ac.uk/safety/subjects/biosafety/subjects/ biosafety/healthcarewastedefinitions. Accessed on 1 July 2014

[3] Bussel Action Network (BAN). Clinical waste in developing countries. Available online at http://www.ban.org/subsidy/clinical.html. Accessed on 5 July 2014.

[4] Johannessen LM, Dijmak M, Bartone C, Hanrahan D, Boyer GM, Chandra C. Healthcare Waste Management guidance note. Washington DC: The World Bank, 2000:64.

[5] Simonsen L, Kane A, Lloyd J, Zaffran M and Kane M. Unsafe injections in developing world and transmission of bloodborne pathogens: a review. Bulletin of the World Health Organisation, 1999; 77 (10): 789-800.

[6] Ferreira V. Teixeira MR. Assessing the medical waste management practices and associated risk perceptions in Algarve hospitals Portugal. www.iswa.it/materiali/iswa_apesb_2009/1-356paper_long.pdf. Accessed on 1 June 2014.

[7] Escaf M, Shurtleff S. A program for reducing biomedical waste: the Wellesley hospital experience. Canadian Journal of Infection Control, 1996; 11(1): 7-11.

[8] Ramokate T, Basu D. Healthcare waste management at an academic hospital: Knowledge and practices of doctors and nurses. South African Medical Journal, 2009; 99(6): 444-445.

[9] Shallini S. Awareness about Bio-Medical Waste Management among Healthcare Personnel of some Important Medical Centers in Agra. International Journal of Environmental Science and Development, 2010; 1(3): 251-255.

[10] Tejas R, Rajaram D, Shalini S, Hemanth, Pruthvish. Knowledge, Attitude and Practices of Paramedical staff regarding Healthcare waste management. Presented at the $2^{\text {nd }}$ National Conference on Students Medical Research, 9-10 January 2009, Medical College, Thiruvananthapuram.

[11] Saini S, Nagarajan SS, Sarma RK. Knowledge , Attitude and Practices of Bio-Medical Waste Management amongst staff of a Tertiary level Hospital in India. Journal of the Academy of Hospital Administration, 2005; 17(2): 1-12.

[12] Shafee M, Kastuwar NB, Nirupama N. Study of Knowledge, Attitude and Practices Regarding Biomedical waste among Paramedical workers. Indian Journal of Community Medicine, 2010; 35(2): 369-370.

[13] Massrouje HTN. Medical waste and health workers in Gaza governorates. Eastern Mediterranean Health Journal, 2001; 7(6): 1017-1024.

[14] Abah SO, Ohimain EI. Healthcare waste management in Nigeria: A case study. Journal of Public Health Epidemiology, 2011; 3(3): 99-110. 
[15] Official website of Nnamdi Azikiwe University Teaching Hospital Nnewi. http://www.nauthonline.com. Accessed on 20 December 2014.

[16] Araoye MO. Research Methodology with Statistics for Health and Social Sciences. Nathadex publishers, Ilorin; 2004: 117120.

[17] Phengxay S, Okumura J, Miyoshi M, Sakisaka K, Kuroiwa C, Phengxay M. Healthcare Waste Management in Lao PDR:A case study. Waste Management and Research, 2005;23 (6): 571-581.
[18] Mostafa GM, Shazly MM, Sherief WI. Development of a waste management protocol based on assessment of knowledge and practice of healthcare personnel in surgical departments. Waste Management, 2009; 29(1): 430-439.

[19] Shalini S, Chauhan SVS. Assessment of biomedical waste management in three apex government hospitals of Agra. Journal of Environmental Biology, 2008; 29(2): 159-162. 